\title{
Well-described concertina effect during coronary angioplasty
}

\author{
Efe Edem, ${ }^{1}$ Mustafa Türker Pabuccu, ${ }^{1}$ Işık Tekin, ${ }^{2}$ Ali Hikmet Kırdök ${ }^{3}$
}

${ }^{1}$ Department of Cardiology, Sakarya University Training and Research Hospital, Sakarya, Turkey

${ }^{2}$ Department of Cardiology, Tarsus State Hospital, Mersin, Turkey

${ }^{3}$ Department of Cardiology, Tinaztepe Hospital, İzmir, Turkey

\section{Correspondence to} Dr Efe Edem,

edemefe@yahoo.com

Accepted 26 April 2015
CrossMark

\section{To cite: Edem $\mathrm{E}$,}

Pabuccu MT, Tekin I, et al. BMJ Case Rep Published

online: [please include Day Month Year] doi:10.1136/ bcr-2015-209895

\section{DESCRIPTION}

A 59-year-old man was referred to our emergency department with a central chest pain at rest that radiated to both arms. He had a history of stent implantation in his right coronary artery (RCA) and his ECG showed signs of previous inferior myocardial infarction. His physical examination was normal and blood pressure was $130 / 80 \mathrm{~mm} \mathrm{Hg}$. Serial measured cardiac enzymes were not elevated, thus the patient was diagnosed with unstable

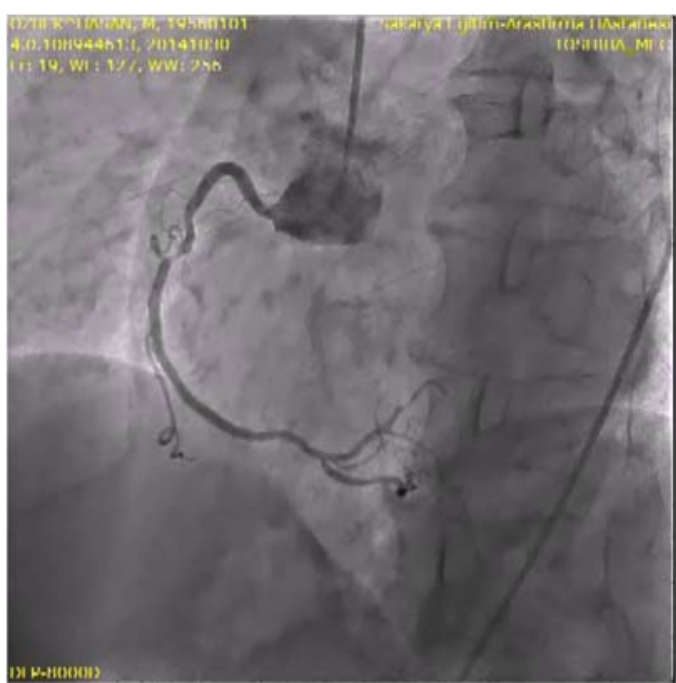

Video 1 Note the severe tortuosity and tight lesion in proximal part of right coronary artery.

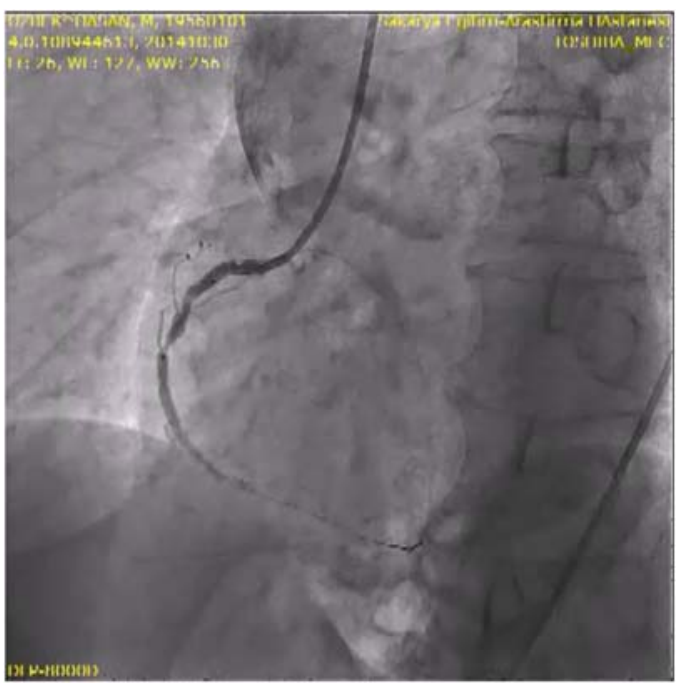

Video 2 Proximal part of right coronary artery showing concertina effect after straightening of the vessel with floppy guidewire and guiding catheter. angina pectoris. On the next day, coronary angiography revealed $40 \%$ stenosis in the mid-portion of the left anterior descending artery and $40 \%$ stenosis in the mid-portion of the circumflex artery. The stent in the mid-portion of his RCA was patent, however, the RCA was markedly tortuous with proximal minor irregularities followed by a 90\% mid-segment lesion (video 1). Percutaneous coronary intervention to mid-RCA was decided. 6F JR4 (Medtronic Launcher, Medtronic Inc,

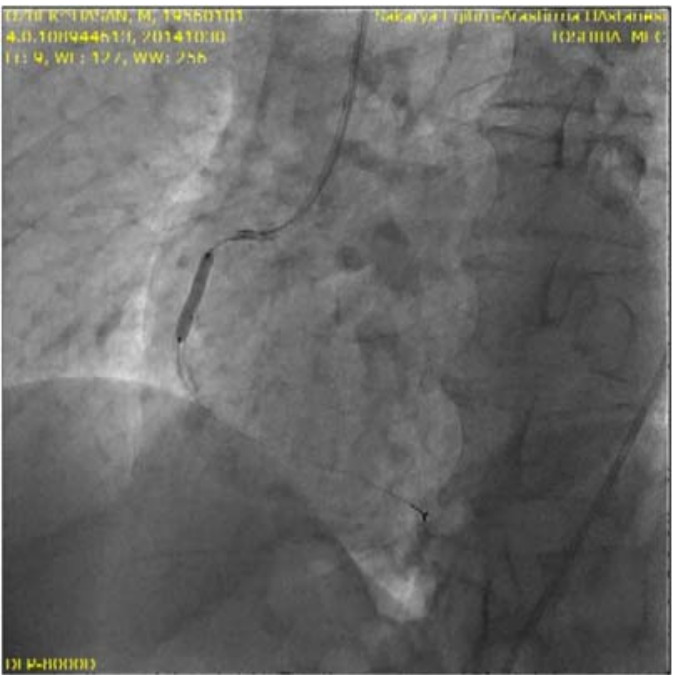

Video 3 Endeavour Resolute 2.5/18 mm drug-eluting stent implantation at $16 \mathrm{~atm}$.

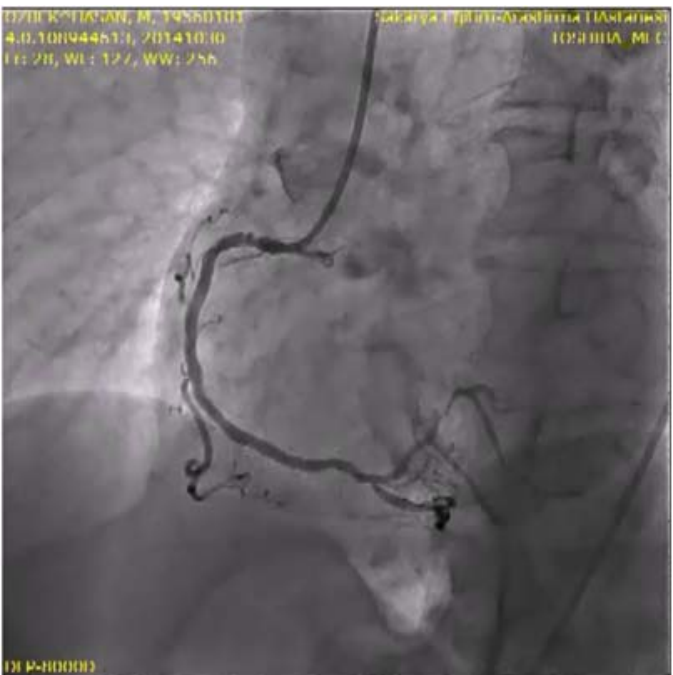

Video 4 Persistence of concertina effect despite multiple doses of intracoronary nitrates while the floppy guidewire and guiding catheter are still in place. 


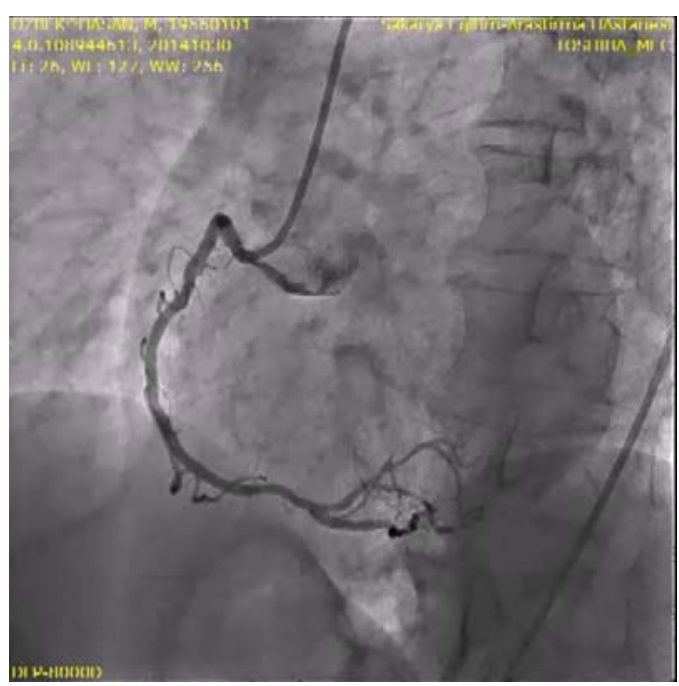

Video 5 Final angiographic view of right coronary artery (RCA) after floppy guidewire and guiding catheter withdrawal. Note the disappearance of proximal pseudolesions (concertina effect) and re-establishing the RCA to its natural geometry.

Minneapolis, Minnesota) guiding catheter was used to engage the RCA. Floppy 0.014 guidewire (Asahi Intecc Co, Pathumthani, Thailand) was used to cross the lesion and was placed distally. We noticed the appearance of a series of new 'pseudo' lesions behind the diseased segment (video 2). An Endeavour Resolute 2.5/18 mm drug-eluting stent (Medtronic Inc, Minneapolis, Minnesota) was deployed at 16 atm (video 3). The final angiographic images revealed evidence of satisfactory final result with $0 \%$ residual stenosis at the stented segment with persistence of the pseudo-lesions behind the stented segment (video 4). Despite intracoronary nitrates, the pseudolesions persisted and only disappeared after guidewire withdrawal (video 5). The patient tolerated the procedure well and was transferred to regular service and continued to be clinically and haemodynamically stable.

A concertina effect is seen when tortuous arterial vessels are straightened with a stiff guidewire. It happens due to geometrical adaptation of the artery. Vasoconstrictive effects caused by guidewire or balloon catheter manipulation, straightening effect, or shortening of the artery at one level and lengthening at another, induce angiographic slit-like multifocal filling defects throughout the longitudinal axis of the artery. The RCA is generally prone to this effect because it is entrenched in the epicardial fat tissue and courses rather freely in the atrioventricular groove. ${ }^{1}$ The concertina effect can be mistaken for dissection or coronary spasm, which may result in unnecessary complex procedures, changing a completely reversible condition into an iatrogenic complication. Concertina effects are usually benign and do not require special intervention. ${ }^{2}$ Vasodilators may be helpful and are strongly recommended, but generally are ineffective in improving pseudostenosis. The preferred therapeutic management is to remove everything from the artery and to re-establish coronary geometry. During procedure, it is reasonable to diagnose a concertina effect while leaving a guidewire inside the coronary artery, and withdrawing it step by step until its floppy tip rests equally on each side of the suspected lesion. ${ }^{3}$

\section{Learning points}

- It is crucial for interventional cardiologists to identify rare iatrogenic events such as the concertina effect. This phenomenon should be managed by pulling out the guidewire and re-establishing coronary geometry as was performed in our case.

Competing interests None declared.

\section{Patient consent Obtained.}

Provenance and peer review Not commissioned; externally peer reviewed.

\section{REFERENCES}

1 Gerasimos G, Loukas KP, Prodromos A, et al. Severe accordion effect: myocardial ischemia due to wire complication during percutaneous coronary intervention: a case report. Cases J 2008;1:138.

2 Mansour S, Adil A. Concertina effect: a memorable phenomenon during coronary intervention. Egypt Heart J 2014;66:71-3.

3 Tsigkas G, Karantalis V, Alexopoulos D. Mechanism of a reproducible accordion phenomenon: insights by optical coherence tomography visualization. J Cardiovasc Med (Hagerstown) 2011;12:583-5.

Copyright 2015 BMJ Publishing Group. All rights reserved. For permission to reuse any of this content visit

http://group.bmj.com/group/rights-licensing/permissions.

BMJ Case Report Fellows may re-use this article for personal use and teaching without any further permission.

Become a Fellow of BMJ Case Reports today and you can:

- Submit as many cases as you like

- Enjoy fast sympathetic peer review and rapid publication of accepted articles

- Access all the published articles

- Re-use any of the published material for personal use and teaching without further permission

For information on Institutional Fellowships contact consortiasales@bmjgroup.com

Visit casereports.bmj.com for more articles like this and to become a Fellow 